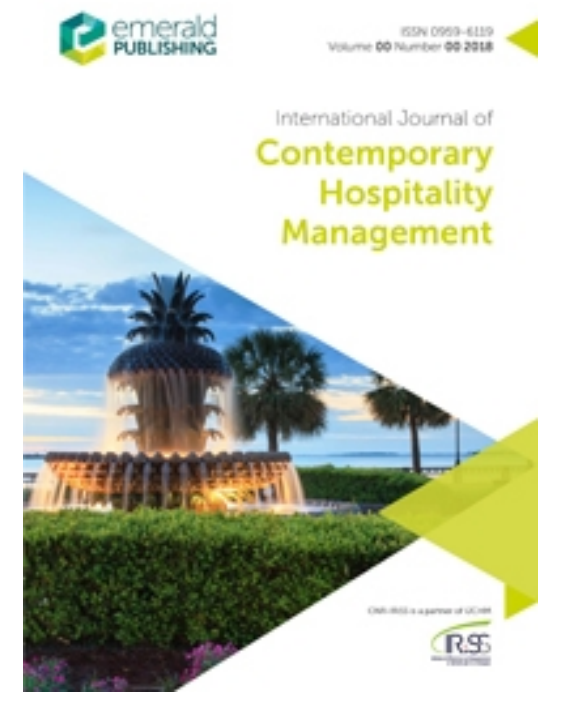

\title{
Pubscape; innovation by design in the British pub
}

\begin{tabular}{|r|l|}
\hline Journal: & International Journal of Contemporary Hospitality Management \\
\hline Manuscript ID & IJCHM-06-2018-0537.R3 \\
\hline Manuscript Type: & Original Article \\
\hline Keywords: & Innovation, Public houses, Sustainable design \\
\hline \multicolumn{2}{|l}{} \\
\end{tabular}

SCHOLARONE
Manuscripts 


\section{Pubscape; innovation by design in the British pub Abstract \\ Purpose}

The decline of the British public house (pub), well documented over the last three decades, is often linked to detrimental social and economic conditions in communities. The purpose of this study was to explore brewery responses to turbulent market conditions for the pub trade, with a focus on innovation through design.

\section{Design}

A longitudinal, qualitative study was conducted over 12 months with four months of close participant-observation within the company, to explore the experiences of a design team located within a medium-sized UK brewery.

\section{Findings}

The 'pubscape' emerged, extending and augmenting earlier models of the 'servicescape', driven by an entrepreneurial shared vision recognising the importance of design and innovation in delivering the modern pub.

\section{Limitations}

A single case - one brewery - formed the basis for a longitudinal qualitative study, with the associated benefits and disadvantages typical of single case research in providing insights rather than measurable outcomes. Other cases and other research methods would allow testing of ideas rather than exploration and generate different perspectives.

\section{Practical}

The research indicates the value of adopting an entrepreneurial approach to address challenging trading conditions and shows the practical role that design can play in rethinking service offerings to fit consumer needs and aspirations.

\section{Originality}

New insights into modern pub management have emerged from this study, positioning design innovation as a route to delivering successful British destination pubs by innovating while retaining traditional brand values and local identity markers, employing the 'pubscape' as a specific way to envisage innovative servicescape environments

\section{Introduction}

This paper discusses a 12-month, longitudinal study of a British brewery company, focusing on a specific response to contemporary market challenges for public houses (pubs), through design innovation (Preece, 2016). According to Sandiford and Divers $(2014,88)$, the English pub 'has adopted an iconic status over the years, with a history stretching back many centuries'. However, despite this long history, reports suggest that large numbers of pubs are struggling in the present economic climate (Cabras and Mount, 2017; Ellis and Bosworth 2015; Pratten, 2003, 2005). Also, despite their continued role in community cohesion (Cabras and Mount, 2017), pubs have seen a steady decline in numbers and profitability over the last 30 years (Roberts and Townshend, 2013), resulting in major changes in pub ownership and management (Andrews and Turner, 2012).

While a range of complex factors have contributed to this decline (see, e.g., Ellis and Bosworth, 2015; Helsey and Seely, 2015), those owning and managing public houses have responded by seeking new ways to attract and retain customers (Andrews and Turner, 2012). Common methods include making adjustments to pricing structures to compete with the lower prices offered in supermarkets, and the re-branding of pubs as bars, restaurants and places for family dining. Making improvements to the physical environment and décor of pub spaces has also been an integral part of many breweries' resilience strategies, often with a change in emphasis; for example, the incorporation of soft play areas in pubs seeking to encourage 
young families and the replacement of traditional wooden furniture with sofas, bookshelves and comfortable armchairs in pubs that serve a dual function as dining places (MCA, 2018).

Pub designs convey a range of values, of both the pub and the brewery, as a core part of their marketing strategy (Alfakhri et al, 2017). Decor typically reflects market positioning, providing variously a 'standardised, hard-wearing functionality or an expression of uniqueness, reflecting contemporary trends in consumer marketing, distinction and branding' (McNeill, 2008, 394). Refurbishing premises is generally understood to improve the attractiveness of the service offering, resulting in positive impacts on sales (Bonnin, 2006). While defining service innovation is problematic (Witell et al, 2016), it may be seen as 'a renewal of an existing service which is put into practice and which provides benefit to the organization that has developed it,' however 'the benefit usually derives from the added value that the renewal provides the customers' (Toivonen and Tuominen, 2009, 893) .

This study explores how one brewery sought to provide a distinctive physical environment in order to establish and renew their brand, providing advantages for their pubs and their brewed products in the process. Previous work emphasises the importance of the physical premises to customer purchase decision-making (Dubé and Renaghan, 2000), responding to consumption choices in order to encourage business growth and profitability. In the context of hotels, 'the physical property of a hotel, which includes the hotel lobby and other public spaces, is very influential in driving the hotel purchase decision' (Countryman and Jang, 2006, 535), this paper relates these ideas to pubs.

Received knowledge of the factors identified in pub refurbishment was first highlighted more than 25 years ago (Pratten, 2007). These centred on estates, but also included responses to government legislation, reduced associations with male working-class culture and a subsequent increase in female patrons, as well as the emergence and proliferation of new, often small-scale brewers. Such themes, together with newer forms of entertainment (such as Sky Sports on television) and an increase in recreational dining experiences, have contributed to the current total marketing and design approach to pubs. The trade has more recently been referred to as 'turbulent' (Preece, 2016), citing new pressures, including changing socioeconomic contexts, technological developments, the 2007 smoking ban, taxation and beer duty, extensive regulation and supermarket competition. Unsurprisingly, for many years, making the correct decisions to invest in marketing and change has been seen as an imperative for the survival of the Great British pub (Pratten, 2003).

The 'public house' is a growing subject for inquiry in Europe and Russia (Kümin and Tlusty, 2017), although UK scholars have largely neglected its role as a social and cultural institution. Additionally, the role of design innovation in the transformation and resilience of the pub trade is yet to be fully described and acknowledged. Addressing these gaps, this study focuses on an independent family-owned brewery and the efforts of the in-house design team to fulfil the vision of senior staff to transform premises into 'destination pubs' as a route to carrying on the company as a successful venture, into the next generation. We followed the brewery's design team over 12 months, as they sought to create, develop and implement new designs for a range of brewery pubs. These activities and their emergent results provide insights into the attitudes and drives of designers and managers functioning in a challenging trading environment, thus making a significant contribution to our understanding of the relationships between market success and design innovation.

\section{The Great British pub}


The British pub has long been popularly viewed as a primary hub for community engagement and social cohesion (Cabras and Mount, 2017). Nevertheless, the structure of the pub trade remains fluid, competitive and challenging with higher duty, declining alcohol consumption and increased competition, changing significantly from the beginning of this century.

Alcohol sales and pub operations have long been licensed and monitored through a range of different regulations, including health and safety and law and order, but Sandiford and Divers $(2014,88)$ credit the Supply of Beer Orders (1989) with causing 'a dramatic revolution' in the structure and practice of British pubs. These acts aimed to open up the sector by eroding 'the monopoly enjoyed by the largest brewers and retailers at that time' (Andrew and Turner, 2012, 543; Pratten, 2007). This resulted in a 'concentration of power in a small number of large pub companies (Pubcos)' specialising in licensed premises, which were then leased to smaller chains or to individual publicans (Mutch, 2004; Preece, 2016; Sandiford and Divers, 2014, 88-89). Rapid consolidation of the brewing sector attempted to achieve economies of scale in production, distribution and marketing (Knowles \& Egan, 2002), moving the structure of the trade away from vertical ownership of pubs by large UK brewers to a range of structures involving independents (Bower, 2016).

The House of Commons report on Pubcos (2004) distinguished between:

- the managed pub, where the company owning a pub, specifies what is sold in it, and hires a salaried manager to run it

- the leased or tenanted pub, where a licensee pays rent to the owner of the property and is often 'tied' to company brands, i.e., required to buy some categories of products from the landlord.

- the freehouse, where the licensee owns the pub, controls the business, makes the buying decisions and takes the profits.

The brewery in this study is a large independent family company with over 200 premises operating as tied and semi-tied pubs, mainly located urban or semi-urban areas. In its pubs, brewery products (three key beers) are required to be sold; in return, the brewery invests in the pub through training updates and repairs to the premises. Although the brewery leases vary in length, longer tenancies are preferred with tenant turnover after short leases identified as a target to address. The participants here define themselves as tenants therefore this is the term used to discuss their needs. Premises updates for tenancies of ten years or more represent a joint investment by both the tenant and the brewery, repairing, and to a certain extent, refurbishing and redesigning the exterior and the interior of the building. Repair decisions are a shared responsibility, typically detailed in the longer tenancy agreements seen in the sample. As such, our study included designers, managers and senior brewery leaders.

\section{Servicescape, design and the public house}

As part of understanding the response of the brewery to changing times, this study considers the public house through the lens of the 'servicescape', which describes 'the role of physical surroundings in consumption settings' (Bitner, 1992, 57; Bonnin, 2006), including the facility exterior, the facility interior and the surrounding environment as value components (Bitner, 1992). This concept has previously been used in the hotel and restaurant industry (Alfakhri et al., 2017; Countryman and Jang, 2006; Zemke et al., 2018) and in retail services (Turley and Milliman, 2000). Exterior premises, the building, signage, parking and landscaping etc., together with interior design, facilities and equipment are part of the services are, together with indoor signage, air quality and temperature. The surrounding environment comprises 'other tangibles - such items as business cards, stationery, billing statements, reports, 
employee appearance, uniforms and brochures' (Bonnin, 2006, 46) to which Turley and Milliman (2000) added human aspects, such as employee and customer characteristics.

In considering design in servicescape creation, we address a lack of research into the role that it plays in creating competitive advantage (Strauss, 2017). Visual, aural, olfactory and tactile aspects form the basis for customer views of a hospitality space, imbuing 'place' and purchase with customer emotion (Essawy, 2017). Hence, by using the right cues for a location, specific feelings can be created in the consumer, which signal or reinforce a purchase decision (Hightower et al., 2002). Furthermore, there has been little application of the servicescape concept to the pub, despite recognising the specific need to update pubs to reflect both changing tastes and changing societal needs (Andrews and Turner, 2012; Cabras and Mount, 2017; Pratten, 2005). Hence, pubs may need to update in response to customer interpretations of their place experience, especially in trying to attract consumers who are conscious of global trends related to what is 'cool' and distinctive (Strauss 2017; Torres and Kline, 2013; West and Purvis, 1992).

Place design evokes feelings and emotions, as value judgments at a product-specific level or as holistic experiences, representing hedonic and utilitarian motivations (Han and Ryu, 2009; Naletelich and Paswan, 2018). Utilitarian consumers seek functionality to fulfil instrumental goals, while hedonic consumers seek consumption experiences fulfilling experiential, symbolic, and emotional desires (Jones et al., 2006; Tangsupwattana, and Liu, 2018; Torres and Kline, 2013). Purchase decisions are rarely solely utilitarian or hedonistic but often a mixture of the two (Babin et al., 1994) such that a purchase may fulfil instrumental, rational needs and motives of time and place while simultaneously meeting hedonic desires for entertainment, excitement and enjoyment (Alfakhri et al., 2017; Torres and Kline, 2013). Therefore, in developing pub premises to attract customers and ensure repeat visits, designers need to understand both utilitarian and hedonistic motivations in their pub servicescape.

\section{Methodology}

This longitudinal research follows the design team as they formulate and implement designs, reflecting on current and past projects, their aims and their understanding of the vision of the brewery management over a 12 -month period. This is complemented by the views of senior and fellow managers about the initiative. In exploring servicescape design evolution, a qualitative method was selected and carried out, using an interpretive approach with 'detailed examination of the participant's lived experience' at work (Crawford, 2013; Smith \& Osborn, 2004, 53), enabling the construction of an 'information-rich case in a detailed but realistic manner' (Miles \& Huberman, 1994; Sonenshein, 2014).

Given the lack of research into the process of pub servicescape formation and the exploratory nature of the study, a case study approach (Yin, 2014) was indicated within an intense, longitudinal framework. Schofield et al (2018; 2503) comment on 'the ontological, epistemological and axiological assumptions of qualitative research'; as in their study, by sourcing information directly from the interviewees and reporting accurately 'their constructed realities based on statements and views expressed during the interviews' credible information was gathered, embedded in the values and world views of the participants.

\section{Sample}

One company was selected to provide a purposive in-depth sample generating rich narratives within a specific context through shared characteristics, given that a 'thick' sample provides the richness that 'thin' samples do not (Drori et al., 2009). The brewery was selected for its 
ambition to be different, as suggested in online and offline documents; to be innovative in its pub environment while retaining traditional values. This suggested a different approach while offering continuity of purpose over the research period (given the same set of people would be involved throughout). It is an unusual rather than an extreme case, to allow practical understanding of design to effect change (Sonenshein, 2014). The company's design team comprised seven designers, led by an experienced designer. Others interviewed were: the senior manager who had identified the need for change, the estate development manager, and the marketing director. In the findings, each is also anonymised as design team DT1-8 and managers M1-3.

The design team operates under two overriding briefs.

1. to reform marketing strategy and increase profitability by repositioning the brand and improving the appearance and functionality of the estate.

2. to create and implement innovative, market-leading interior/exterior schemes which are sympathetic to the values, history and heritage of the brand.

Although all participants interviewed had great faith in (and enthusiasm for) the senior manager's vision of the transformation of these pubs, their own vision differed slightly. To reposition the brewery's brand, designers and brewery management wanted to offer an antidote to homogenous 'chain' pub experiences, while designers wanted to be seen as the best in their field by design peers, as 'leading edge' in the words of participants DT 1, 2, 4 and 7. This required a commitment to innovation and to the company's unique heritage in order to become leaders in the provision of bespoke destination pubs.

\section{Data collection}

Data collection was carried out through three sources of information: semi-structured interviews, participant observation over 4 months and review of relevant online and offline materials. Observation was important in understanding the physical environment and its meanings from the perspectives of the participants (Czarniawska, 2018) with sequential reflection and action to support explanation of behaviours and articulation of activities by participants, thus teasing out the tacit knowledge embedded in actions (Cross, 2001).

Thus, researchers took part in the 'daily activities, rituals, interactions, and events' of participants, to learn 'the explicit and tacit aspects of their life routines and their culture' (Dewalt and Dewalt, 2002, 1; Torres, 2016). Four months day-to-day observation included free interactions and group dynamics, together with identification of the insider's language (i.e., the participants) and the outsider's language (i.e., the researcher) (Spradley, 1979). This was overt rather than covert participant observation (Torres, 2016). The time spent by the researcher within the firm helped to build open and trust-based relationships with the participants (Christou, 2006; Fontana and Frey, 1994; Minichiello et al., 1995), supporting the transition from stranger to member to insider (Czarniawska, 2018)

Prior to the observation periods, meetings were held with all participants as a group and singly to ensure the aims and methods of the project were understood. Participant observation was accompanied by a series of 4 individual semi-structured interviews with each of the main participants (44 interviews altogether). These were conducted on an individual, face-to-face basis on company premises lasting 45 to 90 minutes, with increasing duration as participants felt more at ease, both to explore current designs and reflect on earlier design projects. In carrying out interviews, the design background of the interviewers necessarily facilitated discussion with designers and meant there were some pre-conceptions in doing so. 
Here we accept that the team exploited their pre-understandings and exploited them reflexively 'as a source of insight' (Finlay, 2009, 13) through shared experience of the subjective components of the 'same' phenomenon ('qualia'). Qualia shape how social action is seen, where 'practice can be linked to groups and become productive of certain kinds of knowledge of 'the way things are' (Harkness, 2015, 574). So, being an interviewee with a design background enabled the discussion of the qualia of design sources and innovation, enriching the data of the study. In this case, it included shared meanings for ideas related to 'design values' and 'symbols' and for how design is conducted.

Interviews were recorded, then transcribed for data analysis using guidelines from Morse \& Richards (2002, 174). Following Crawford (2013), themes for discussion were introduced, supported by planned cues to aid discussion flow. These themes firstly focused on participant perspectives of the nature of their roles, the way things worked in the company and what terms such as design meant to the individual. Once observation began, themes emerged from observation which gave participants opportunities to reflect on how and why things had happened and comments about decisions were also collected, as they happened.

Observation included not only design team members but also brewery company members, tenants and customers, known to the research team through repeated meetings and discussions as part of the daily life of the company. This meant entering into conversation with participants in 'live' situations to determine their interpretations of observed events using established methods (Drori et al., 2009). The design team's previous online and offline documentation such as design briefs, drafts and emails plus their on-going documents positioned the observation contextually.

The data was analysed inductively (Drori et al, 2009; Miles and Huberman, 1994). As in Schofield et al., (2018), data collection, analysis and evaluation were carried out continuously and simultaneously rather than sequentially. Each interview text was analysed thematically as follows (Miles \& Huberman, 1994). The first stage of this analysis involved temporal and contextual categories, which had been recorded chronologically, including participant views of such aspects as planning, design briefs and their development, values, gut feeling, issues, risk and resources, everyday life, interactions, other people, aims and culture.

Open coding allowed themes to be identified across interviews, with similar identification across notes of observation. Subsequently, researchers reviewed texts from interviews and observation for phrases, sentences or paragraphs, which facilitated the researchers' understanding of servicescape formation. The final stage was to categorise the phrases and open coded themes into meta-themes against relevant theory for interpretation. Final categorisations were reached after subsequent discussion and are shown as Table 3. This categorisation took place around formal/informal processes related to project design, capturing participant views in these areas (Strauss and Corbin, 1997). In this way, the researchers identified those preconceptions around design and design values allowing better understanding of participant comments.

Results are reported as five sections, summarising the design process, then reporting the aggregate categories from Table 3: vision, values, innovation and pub servicescape / pubscape. In developing aggregates, separating vision and innovation was at times difficult, given the blanket use of the word by participants. In the end though these are differentiated as 
vision - seeing the end goal as- opposed to innovation - the actions implementing the vision. Designers and senior managers conceptualise 'vision' as a route to long term advantage through dramatic change and see 'innovation' as a the actions needed to deliver this vision. Brewery managers and tenants on the other hand are more focused on practical changes to deliver profits by attracting new customers while retaining existing customers. As a result their views for short-term aims are represented as innovation rather than vision as they are focused on practical applications of the vision.

\section{Findings}

\section{Process}

The design team was responsible for at least 5 premises at a time, with project briefs ranging from superficial decoration upgrades (termed a 'sparkle' by team members) to full transformations of both interior and exterior spaces. Budgets extended from $£ 15000$ to $£ 2$ million for these transformations or for new pubs and involved both brewery and tenants. The comments of the design team, and the observed practice of interaction with other stakeholders, showed all the general elements of the servicescape identified by Rosenbaum and Massiah (2011) in Figure 1.

The development of destination pubs was led by the design team, with considerable input from brewery and tenants who are investing in premises update, as well as from customers seeing change planned for 'their' local. The brewery therefore managed the design team through an inclusive process of collaboration and development with the precise location and environment. To understand how pub servicescapes are developed, this study focuses on the redesign and new design of pubs owned by one independent regional family brewery, through the perspectives of their in-house design team, estates managers and directors over a period of time when projects to redesign and relaunch pubs were designed, ongoing and completed.

Refurbishment was planned and researched countering Bitner, (1992), in her view that change occurred without considering the impact of a specific design or atmospheric change on users. The historic background of the brewery was celebrated and positioned within local identity, retaining core values while upgrading pubs to meet changing tastes and to attract different customers (Andrews and Turner, 2012; Cabras and Mount, 2017; Pratten, 2005). More detailed findings are discussed in terms of servicescape. Further, after reviewing Figure 1, which provides an environmental framework for the servicescape, the data was mapped to provide a pub servicescape as seen in Table 2.

\section{Vision}

For senior managers the long-term vision was to reposition the brewery in the marketplace, responding to changing tastes and regulatory changes by aligning their pubs with modern tastes and lifestyles. By establishing their premises as destination pubs, 'places to be' they hoped to gain and retain an extended customer base to ensure business sustainability. This vision was echoed in conversation with the design team, aiming to achieve the uniqueness suggested by McNeill (2008):

'What we want to be known for is that every time you see something with the brewery name over the door, there's something amazing inside.' (DT1).

This was also reflected in their view of customer perceptions

'It's......the IKEA generation. Everyone's a designer, everyone wants to have trendy spaces - and that certainly works in pubs because now we can't get people to pay good prices for alcohol if the interior's not first class' (DT2). 
The internet and access to opinion formers also informed ideas for new pub designs, as did online reviews about the nature of the experience in the pub, where views of colour, comfort and ambiance were shared. Where the refurbishment was publicised in stages to engage customers, this also came with potential anxieties for the designers:

'People are just so much more informed - you can go on Twitter and type in the name and you can find what it's all about before you go anywhere. So if you're getting it wrong, everyone'll know about it straight away because people tweet about it, and if you get it right, you want everyone to turn around and say, 'that's spot on.'(DT4)

Uniqueness and distinctiveness was a core aim, carried through the whole design including artefacts such as lighting and chairs, which were designed around the core project idea (as in McNeill, 2008) One participant held up a light fitting made from a handle pint glass and explained, 'This a unique product. This is the only one (like it) in the world.' (DT4).

DT2 commented on the way people would see their new refurbishments as unique because they would never have seen anything like it:

'If we can't find something that's unique we will design something.' (DT3).

This was important since each pub was unique. Each refurbishment was seen as similarly unique and needing ideas to support that.

'Architecture and building is probably the only industry where you're building the prototype of your design and finish with it... You don't get Ford come up with a concept for a car, make one and then move on to something else, but that's what we do all the time and so you never have the same building to deal with twice.' (DT7).

In developing a unique design, the role of symbolic artefacts emerged, shaping initial design perspectives, 'you'll see something, but you'll kind of look beyond it, like how that was made, how was that thought about and manufactured and- use it as a basis' (DT2). The balance of old and new shaped the key theme for each pub and determined the nature of the atmospherics in terms of colour, music, lighting, furnishing and layout (Alfakhri, et al., 2017; Rosenbaum and Massiah, 2011) signalling modernity while encouraging feelings of comfort, warmth and tradition (Strauss, 2017).

\section{Innovation}

For brewery managers, innovation meant actions to create value (Toivonen \& Tuominen, 2009); for the design team it was about practical leading-edge creative design. Participants explained that innovation was embedded in their whole approach to the redesign of the pub experience, exterior and interior and including signage, lighting and furniture, with implications for how customers were served and looked after by the human elements.

Innovation was enabled by knowledge of the industry and keeping up-to-date with critical developments, providing a constantly changing store of design and product knowledge (Lee et al., 2012) which could be visualised and drawn upon during the early development of a scheme. The company supported this via initiatives to enhance design and product knowledge through attending national and international design shows. Designers were always looking for new ideas to support their core mission of uniqueness and distinctiveness:

'Sometimes when you're out you'll see something, but you'll look beyond it, like how was that made, how was that thought about and manufactured to kind of try and break it down to then replicate it yourself and kind of tweak it - use it as a basis.' (DT5) 
This also meant scoping the competition, reviewing pubs and bars run by other companies and in other locations. One explained that they had at first travelled to London to look at what was happening there but then realised that many of the newer ideas came from overseas trade shows:

'...so we went to Paris...[thinking] let's be the cutting-edge ones... ... We want a bit of what's going on there in our pubs before anyone else does .. pushing the boundaries a bit and specifying and buying products from suppliers that probably people locally hadn't heard of yet...' (DT1)

Innovation had to be practical though and required 'thinking from the tenant's perspective' for the tenant needed to make the business work:

'Once I've been in there and done it and left they've got to operate that pub... Sometimes you've got a feeling that says, 'that looks great', but operationally it doesn't work, so you've got to balance what is more important. Obviously you want it to look good but for them, the main thing is them making money, making profit, it's got to work.' (DT2)

\section{Values and Design processes}

Interactions surrounding new or refurbished pub design projects involved the brewery and tenant and the pub customers, despite the difficulty of working to so many sets of expectations and ideas where 'everyone's going to have an opinion' (DT7). The weight given to these opinions differed but negotiation and compromise were necessarily built into project development. 'They're the client so you have to...bend over backwards sometimes' even though sometimes it was to the detriment of the scheme...' (DT3).

There was also the historic viewpoint, given that many of the existing pubs had very traditional décor and feel. 'We're doing a pub rebrand at the moment... and a lot of that is wrestling with the fear of - how do we modernise it without abandoning our heritage? (DT2).... There's a lot of history, you know, and we're really proud of it, so we don't want to throw that away' (DT1).

Internal brewery discussions and actions by managers of other functions within the brewery was a source of difficulty for the design team, where commercial concerns were felt to override design values. Internal competition between managers might result in impaired implementation of the original design:

'The estates manager gets really massively frustrated by that - like the commercials will want to put an advert or something pretty naff - an image - right in the middle of something he's spent a lot of time on that we've been designing....or there'll be a lovely, beautiful bar and the retail guys want to put a huge great fridge right in the middle of it because they want to promote a certain chilled wine, something like that.' (DT3)

Beyond internal issues, pub tenant views included anxieties over losing regular pub customers as a result of their commitment of money and emotion in the refurbishment:

'Some landlords describe older, regular customers who come in and sit in a particular seat in the corner, who don't see anything wrong with the pub, they kind of love it as it is, so you have to do it really quite sympathetically.' (DT7)

High production values were stressed in every project, not only to meet the brewery's vision but also to establish and retain their own prior high reputation as designers, which they had 
gained as a design company prior to the association with the brewery. Retaining your reputation meant being aware of others judging the concept and how it was put into practice from a design perspective:

'It's a big driver ...you don't want people to be going into that pub and thinking' (it's no good) ... 'it's got your name at the top' (DT4).

Retaining the reputation also meant consistency, with pressures to get the design right every time: 'you're only as good as your last scheme' (DT5).

\section{The pub as servicescape}

Comparing the pub to the models of a servicescape required physical, social, social symbolic and natural dimensions as shown in Figure 1 (Rosenbaum and Massiah, 2011, 473). A new feature for the model was TV and Wi-Fi, since customers 'expect the Wi-Fi technology to work and to be able to see sports events important to them in congenial surroundings, or to be able to escape them!' (D2). Managing sound then becomes an issue that can be built into the refurb 'but then relies on the tenant and staff to maintain'. (D1).

These had become embedded in customer expectations as necessary for the utilitarian function of the pubscape (Babin et al., 1994). The whole experience therefore had utilitarian features but appealed to hedonistic needs for fantasy:

'It's like a stage set, where for a couple of hours you're going to experience something that you're won't at home... the branding, the marketing, the service from the staff...the interior, the scheme, the lighting, the whole ambience, aesthetics - a journey for (the customer) from start to finish which they're happy with and go away talking about because ultimately that means they'll come again.' (DT3)

These terms used to describe the finished design reflect servicescape being a total product (Bitner, 1992). Having developed and implemented the design team, this was a 'total experience' for customers (Hightower et al., 2002). 'Putting yourself in the customers' shoes' was a common phrase, as was the view that the experience or the total experience was what customers expected and that they would generate new customers through word of mouth or social media to tell others about the place:

'You want them to instantly like it, and instantly want to come back... On walking in you want them to kind of - not be blown away by it necessarily - but to feel comfortable and happy in the interior... You want it to pass on from person to person' (DT6).

This 'passing on from person to person' was both online and offline. The integrated design and marketing function incorporates not only industry reports and social trends but also the views of tenants and customers. By reviewing and measuring engagements in different social media (through Google Analytics, by monitoring TripAdvisor and similar sites, through Facebook and Twitter) the brewery assessed the impact of new designs on voiced customer perceptions, supplementing standard beer and food consumption figures or profit and turnover to show sustained customer enthusiasm for these pubs.

\section{Discussion}

The design team brought 'people, products or practices from the world of the arts' into the brewery, delivering a revitalised 'pubscape' (Berthoin Antal, 2012, 45). This was a deliberate strategy, fulfilling senior manager ambitions to raise the profile of their pubs and to position them differently in the marketplace (Pratten, 2003, 2007; Preece, 2016). This included researching current and potential customer needs and aspirations before taking action to 
improve the servicescape, counter to Bitner's research (1992). The senior management vision was reflected by the designers in their ambition to deliver uniqueness in pubs such that 'every time you see something with the brewery name over the door, there's something amazing inside' (DT1), building the customer response through cues to positive emotions (Alfakhri et al., 2017; Hightower et al., 2002).

Each pub project aimed to create a unique experience, carried out holistically to engage the customer by connecting 'place' and purchase with customer emotion (Hightower et al., 2002). The processes carried out by the design team transformed premises into a pubscape, drawing elements together to create a new service offering for the customer (Alfakhri et al., 2017). In the words of DT2, it was necessary to- 'think of the whole project as one... and look at it as a whole'. Designers also balanced the utilitarian needs of tenants in terms of budgets and business and with both utilitarian and hedonistic needs of customers in finished designs emphasising enjoyment, fantasy and fun (Jones et al., 2006; Torres and Kline, 2013). Hence, these designs enabled customers to receive gratification not just from the purchase of drinks but also from the holistic pub experience which aligned with their mood and lifestyle aspirations (Babin et al., 1994; Strauss, 2017).

This process was understood and appreciated by managers, who saw designs delivering innovative pub experiences while highlighting and promoting what was best in the brand. Surveys at refurbished pubs showed that the loyalty base had increased, retaining existing customers and attracting new types of customers, suggesting a successful route to address decline by gaining market share (Andrews and Turner, 2012; Ellis and Bosworth, 2015; Helsey and Seely, 2015). This goes beyond simple improvements to the physical environment to redesigned environments, which engage and capture the imagination and lifestyle aspirations of new customers (Bonnin, 2006; Dubé and Renaghan, 2000; McNeill, 2008).

Pubs innovate through the use of 'form and function' (Strauss, 2017), using design to enable strategic positioning to attract consumers (Countryman and Jang, 2006; Zemke et al., 2018). Here design is art with a purpose, meeting the brewery's need for strategies to improve market share (Esslinger, 2009; Strauss, 2017; West and Purvis (1992). Symbolic artefacts were a source of inspiration capturing and representing values or generating particular emotions. Design is potentially creating value through reconfiguring pubs and an accompanying reinvigoration of the company, addressing gaps in knowledge related to the connection between design and competitive advantage (Strauss, 2017; Yin et al., 2011).

In exploring the feelings and emotions evoked by place design, consumers make value judgments at a product-specific level or as holistic experiences, representing two distinct types of motivations: hedonic and utilitarian (Han and Ryu, 2009; Naletelich and Paswan, 2018) . Utilitarian consumers focus on functionality to fulfil instrumental goals, whereas hedonic consumers seek consumption experiences fulfilling experiential, symbolic, and emotional desires (Jones et al., 2006; Tangsupwattana, and Liu, 2018; Torres and Kline, 2013). Purchase decisions are rarely solely utilitarian or hedonistic; often decision-making involves a mixture of the two (Babin et al., 1994) fulfilling instrumental expectations to meet rational needs and motives of time, place and ownership while simultaneously meeting hedonic desires for entertainment, excitement and enjoyment (Alfakhri et al., 2017; Torres and Kline, 2013). Therefore, in developing pub premises to attract customers and ensure repeat visits, designers need to understand both utilitarian and hedonistic motivations in their pub servicescape. 
The mood, look and feel of the pub created value by responding to 'a consumer's appreciation of 'aesthetic' elements intrinsic to a consumption setting that are manifest in the visual appeal' (Mathwick et al., 2002, 53), going beyond the visual. While retaining functional elements, the pubs 'engaged the imagination and created a memorable experience' appealing to both utilitarian and hedonic consumer needs (Babin et al., 1994; Childers et al., 2001, 514). Designing locations to evoke specific emotional effects enhances the probability of purchase (Alfakhri et al., 2017), adding value (Dubé and Renaghan, 2000) and improving business performance (Zemke et al., 2018). Addressing earlier research on the need to change (Pratten 2003, 2007), customers were attracted to the designs, especially women and those with higher disposable income seeing the pubs as fitting a more aspirational lifestyle, i.e., picking up on global trends related to what is 'cool' and distinctive (Strauss 2017).

\section{Conclusions}

The study offers new insights into design as innovation in the pub trade and indicates novel approaches to current market challenges by brewery management. Here innovation creates organizational value by applying new ideas and approaches (Lee et al., 2012), revealed through single case study detailed results. In doing so, the study also offers a new perspective on the servicescape concept by applying it to a societal icon - the British pub - with both utilitarian and hedonistic perspectives embodied in new design in order to deliver the company vision of 'bespoke destination pubs'.

More than this, however, it shows how the pub can be thoroughly reinvented to retain its place in the British leisure landscape, without losing its heritage. The brewery chose to renovate, 'to keep up with the competition, to maintain and increase market share and to comply with new trends and technology' (Hassanien, 2007, 43). The brewery had a vision for the future and chose design as a route to envisage and action change (Heskett, 2009; Zemke et al., 2018). For the brewery leadership and the design team, the building embodied the values, and ethos of the brewery and was the key to competitive advantage through distinctive and differentiated design excellence (McNeill and McNamara, 2009). The route to developing this excellence required shared aspirations and innovation which led to design solutions successful in attracting and retaining new types of customers without alienating traditional loyalties (Pratten, 2003, 2007).

\section{Theoretical implications}

By exploring how this brewery developed its customer experience strategy, a new approach to the servicescape approach initially suggested by Bitner (1992) emerged, which we termed 'pubscape'. Pubscape builds on existing servicescape theory (such as the model by Rosenbaum and Massiah, 2011, see Figure 1) to envisage a new complex service environment useful in different types of pubs to map and understand customer experience. This new concept - pubscape - emerged through the dynamic interplay of expectations from multiple stakeholders, all with strong ideas about what 'the pub' is now and how it should look and feel, in the future. This is shown in Figure 2, which models how the pubscape evolved through an interplay of different expectations and a shared vision.

Addressing the lack of research into the role that design plays in creating competitive advantage in hospitality contexts (Preece, 2016; Strauss, 2017), this study shows that pubs need to address practical and aesthetic needs in providing destinations to visit (Alfakhri et al., 2017). The new designs sought to retain the emotional pull of the traditional and the familiar while presenting unique experiences 'destinations', reflecting contemporary trends in 
consumer marketing, distinction and branding (McNeill, 2008), while identifying the way both utilitarian and hedonistic customer needs were met, as seen in earlier research in hotel contexts (Alfakhri et al., 2017; Torres and Kline, 2013). Pubs were therefore designed to embody both 'form and function' (Strauss, 2017), in a strategy to extend market reach without losing existing customers (Countryman and Jang, 2006; Zemke et al., 2018).

\section{Practical Implications}

From a practical standpoint, breweries might implement service innovation by marketing a brand image that shows pubs are innovative locations, aligned with current customer needs and aspirations. This could help them to enhance their relationships with existing customers and increase their reach with new customers, through products and premises being seen as part of modern lifestyles. The brewery's project review indicated that the redesign has been successful in attracting and retaining new customers in a competitive trading environment, with resulting plans for the redesign of the rest of the pubs it owns. Drawing tenants and customers into the process added to the excitement and raised the profile of new designs, with pubs felt by all parties to be innovative but still true to local expectations.

Initially breweries could employ some of the same techniques as this case study suggests, using design as a way to reposition their brand and doing so in ways that will engage and surprise existing customers who may feel these are fun, exciting and enjoyable, while attracting new customers. For those managing breweries and individual pubs, the application of pubscape - an updated servicescape view- as a way to review the service offering offers a way to reposition products and places to excite customer interest and engage new types of customers. Through design and redesign, the brewery tapped into new markets to ensure its longer-term viability but how does this relate to the sector as a whole?

The development of pubscape as described by the design team is based on innovation in style, repositioning pubs as destinations fitting current customer expectations and aspirations. The implications for other breweries may be to approach challenging times more entrepreneurially, applying this model in their own context rather than focusing only on pricing or cost cutting. This would, however, require the same vision, level of financial investment and the same rigour in market research throughout the process. In uncertain times for breweries, a new approach is called for if the pub is to retain its place as a valued part of the leisure landscape.

\section{Limitations and future research}

The research has focused on one brewery in a longitudinal qualitative study. Will this approach, tested and found to work in small market towns and city centres, enjoy the same success in rural hamlets? The study has the benefits and disadvantages typical of such research in providing insights rather than measurable outcomes. Other cases might provide different results related to responses to pub decline. Similarly, the adoption of other research methods would allow testing of ideas rather than exploration. Repeating the study in another geographical context or with different types of beer companies might also generate different perspectives.

\section{References}

Alfakhri, D., Harness, D., Nicholson, J., \& Harness, T. (2017). The role of aesthetics and design in hotelscape: A phenomenological investigation of cosmopolitan consumers. Journal of Business Research. 85(1), 523-531. 
Andrews, D., \& Turner, S. (2012). Is the pub still the hub?. International Journal of Contemporary Hospitality Management, 24(4), 542-552.

Babin, B. J, Darden, W. R \& Griffin, M. (1994). Work and/or fun: measuring hedonic and utilitarian shopping value, Journal of Consumer Research, 20(4), 644-656.

Berthoin Antal, A. (2012). Artistic intervention residencies and their intermediaries: A comparative analysis. Organizational Aesthetics, 1(1), 44-67.

Bitner, M. J. (1992). Servicescapes: The impact of physical surroundings on customers and employees. Journal of Marketing, 56(2), 57-71.

Bonnin, G. (2006). Physical environment and service experience: an appropriation-based model. Journal of Services Research, 6(1), 45-65.

Bower, J. (2016). Vertical and financial ownership: Competition policy and the evolution of the UK pub market. Business History, 58(5), 647-666.

Cabras, I., \& Mount, M. P. (2017). Assessing the impact of pubs on community cohesion and wellbeing in the English countryside: a longitudinal study. International Journal of Contemporary Hospitality Management, 29(1), 489-506.

Childers, T. L, Carr, C. L., Peck, J., \& Carson, S. J. (2001) Hedonic and utilitarian motivations for online retail shopping behaviour, Journal of Retailing, 77(4), 511-535.

Christou, E. (2006). A qualitative analysis of consumer attitudes on adoption of online travel services. Tourism 54(4), 323-331.

Countryman, C. C., \& Jang, S. (2006). The effects of atmospheric elements on customer impression: the case of hotel lobbies. International Journal of Contemporary Hospitality Management, 18(7), 534-545.

Crawford, A. (2013) Hospitality operators' understanding of service: a qualitative approach, International Journal of Contemporary Hospitality Management, 25(1), 65-81.

Cross, N. (2001). Designerly ways of knowing: Design discipline versus design science. Design issues, 17(3), 49-55.

Czarniawska, B., (2018). Fieldwork Techniques for Our Times: Shadowing. In Qualitative Methodologies in Organization Studies (pp. 53-74). Palgrave Macmillan, Chambers,

Drori, I., Honig, B., \& Wright, M. (2009) Transnational entrepreneurship: An emergent field of study, entrepreneurship theory and practice, 33(5), 1001-1022.

Dubé, L., \& Renaghan, L. M. (2000). Creating visible customer value: How customers view best-practice champions. Cornell Hotel and Restaurant Administration Quarterly, 41(1), 6272.

Essawy, M. (2017). The impacts of e-atmospherics on emotions and on the booking intentions of hotel rooms. Tourism and Hospitality Research, 1467358417692393.

Esslinger, H. (2009). A fine line: How design strategies are shaping the future of business. John Wiley \& Sons.

Ellis, V., \& Bosworth, G. (2015). Supporting rural entrepreneurship in the UK microbrewery sector. British Food Journal, 117(11), 2724-2738.

Finlay, L. (2009). Debating Phenomenological Research Methods. Phenomenology \& Practice, 3, 6-25.

Fontana, A., \& Frey, J. H. (1994) Interviewing: The Art of Science. In Denzin, N., \& Lincoln, Y. (eds) The Handbook of Qualitative Research, Sage, 361-376.

Han, H. and Ryu, K., (2009). The roles of the physical environment, price perception, and customer satisfaction in determining customer loyalty in the restaurant industry. Journal of Hospitality \& Tourism Research, 33(4), pp.487-510.

Harkness, N., (2015). The pragmatics of qualia in practice. Annual Review of Anthropology, 44, pp.573-589.

Hassanien, A. (2007). An investigation of hotel property renovation: The external parties' view. Property management, 25(3), 209-224. 
Helsey M. And Seely A, (2015), Pub companies, pub tenants \& pub closures: background history (up to 2014) Standard Note: SN6740 13 May, House of Commons Library, Business and Transport Section.

Heskett, J. (2009). Creating economic value by design. International Journal of Design, 3(1), 71-84.

Hightower Jr, R., Brady, M. K., \& Baker, T. L. (2002). Investigating the role of the physical environment in hedonic service consumption: an exploratory study of sporting events. Journal of Business Research, 55(9), 697-707.

House of Commons, (2004), Pub Companies - Business and Enterprise Committee, HC 128-I, https://publications.parliament.uk/pa/cm200809/cmselect/cmberr/26/2604.htm, 21 December Jones, M. A., Reynolds, K. E., \& Arnold, M. J. (2006). Hedonic and utilitarian shopping value: Investigating differential effects on retail outcomes. Journal of Business Research, 59(9), 974-981.

Knowles, T., \& Egan, D. (2002). The changing structure of UK brewing and pub retailing. International Journal of Contemporary Hospitality Management, 14(2), 65-71. Kümin, B., \& Tlusty, B. A. (2017). The world of the tavern: Public houses in early modern Europe. Routledge.

Lee, Olson, \& Trimi, S., 2012. Co-innovation: convergenomics, collaboration, and cocreation for organizational values. Management Decision, 50(5), pp.817-831.

Mathwick, C., Maholtra, N. K., \& Rigdon, E. (2002) The effect of dynamic retail experiences on experiential perceptions of value: an internet and catalog comparison, Journal of Retailing, 78(1), 51-60.

MCA, (2018), UK Pub Market Report 2018, 3 July, https://www.mca-insight.com/marketintelligence/market-reports/uk-pub-market-report-2018/568871.article Accessed November McNeill, D. (2008). The hotel and the city. Progress in Human Geography, 32(3), 383-398. McNeill, D. and McNamara, K. (2009), 'Hotels as civic landmarks, hotels as assets: the case of Sydney's Hilton', Australian Geographer, Vol. 40 No. 3, pp. 369-386.

Miles, M.B., \& Huberman, M. A. (1994) Qualitative Data Analysis: An Expanded Sourcebook, Sage.

Minichiello, V., Aroni, R., \& Hays, T.N. (1995) In-Depth Interviewing: Principles, Techniques, Analysis, Pearson Education Australia.

Morse, J. and Richards, L., 2002. Read me first for a user's guide to qualitative research. CA, US: Sage Publications Thousand Oaks.

Mutch, A. (2004). Shaping the public house, 1850-1950: Business strategies, state regulation and social history. Cultural and Social History, 1(2), 179-200.

Naletelich, K., \& Paswan, A. K. (2018). Art infusion in retailing: The effect of art genres. Journal of Business Research. 85(1), 514-522.

Pratten, J. D. (2003). Responding to demand: new types of public houses in the UK. Journal of Food Products Marketing. Vol. 19 No. 2 Haworth Press, Binghamton, New York pp.39-52 Pratten, J. D. (2005). Rent and the lessee. International Journal of Contemporary Hospitality Management, 17(2), 157-169.

Pratten, J. D. (2007). The development of the UK public house: Part 2: signs of change to the UK public house 1959-1989. International Journal of Contemporary Hospitality Management, 19(6), 513-519.

Preece D. (2016) Turbulence in UK Public House Retailing: Ramifications and Responses. In: Cabras I., Higgins D., Preece D. (eds) Brewing, Beer and Pubs. Palgrave Macmillan, London

Roberts, M., \& Townshend, T. (2013). Young adults and the decline of the urban English pub: issues for planning. Planning Theory \& Practice, 14(4), 455-469. 
Rosenbaum, M. S., \& Massiah, C. (2011). An expanded servicescape perspective. Journal of Service Management, 22(4), 471-490.

Sandiford, P. J., \& Divers, P. (2014). The English public house as a 21 st century socially responsible community institution. International Journal of Hospitality Management, 41, 8896.

Schofield, P., Crowther, P., Jago, L., Heeley, J., \& Taylor, S. (2018). Collaborative innovation: catalyst for a destination's event success. International Journal of Contemporary Hospitality Management. (in press).

Smith, J.A. and Osborn, M., (2004). Interpretative phenomenological analysis (pp. 229-254). The British Psychological Society and Blackwell Publishing Ltd.

Sonenshein, S., (2014). How organizations foster the creative use of resources. Academy of Management Journal, 57(3), pp.814-848.

Spradley, J. P. (1979). Ethnography and culture. The ethnographic interview. Holt, Rinehart, and Winston: Florida.

Strauss, A. (2017). Value-creation processes in artistic interventions and beyond: Engaging conflicting orders of worth. Journal of Business Research. 85(1), 540-545.

Strauss, A. L., \& Corbin, J. M. (Eds.). (1997). Grounded theory in practice. Thousand Oaks, CA, US: Sage Publications, Inc

Tangsupwattana, W., \& Liu, X. (2018). Effect of emotional experience on symbolic consumption in Generation Y consumers. Marketing Intelligence \& Planning.

Toivonen, M. and Tuominen, T., 2009. Emergence of innovations in services. The Service Industries Journal, 29(7), pp.887-902.

Torres, E. N., \& Kline, S. (2013). From customer satisfaction to customer delight: Creating a new standard of service for the hotel industry. International Journal of Contemporary Hospitality Management, 25(5), 642-659.

Torres, E.N., (2016). Guest interactions and the formation of memorable experiences: an ethnography. International Journal of Contemporary Hospitality Management, 28(10), pp.2132-2155.

Turley, L. W., \& Milliman, R. E. (2000). Atmospheric effects on shopping behaviour: a review of the experimental evidence. Journal of Business Research, 49(2), 193-211.

West, A., \& Purvis, E. (1992). Hotel design: The need to develop a strategic approach. International Journal of Contemporary Hospitality Management, 4(1) 14-22 Witell, L., Snyder, H., Gustafsson, A., Fombelle, P. and Kristensson, P., (2016). 'Defining service innovation: review and synthesis'. Journal of Business Research, 69(8), pp.28632872.

Yin, R. K. (2014) Case Study Research Design and Methods, Sage.

Yin, Y, Qin, S., \& Holland, R. (2011). Development of a design performance measurement matrix for improving collaborative design during a design process', International Journal of Productivity and Performance Management, 60(2), 152-184.

Zemke, D. M. V., Raab, C., \& Wu, K. (2018). How does hotel design contribute to property performance? International Journal of Contemporary Hospitality Management, (justaccepted), 00-00. 


\begin{tabular}{|l|l|l|}
\hline Table 1 Interviewees for 4 interviews over 12 months and observed over 4 months \\
\hline MT1 & $\begin{array}{l}\text { Senior management team, } \\
\text { director, family member }\end{array}$ & $\begin{array}{l}\text { Developed the vision to develop the premises as } \\
\text { destination pubs to take through a strong brand to } \\
\text { the next generation }\end{array}$ \\
\hline MT2 & $\begin{array}{l}\text { Management team } \\
\text { Marketing lead for company }\end{array}$ & $\begin{array}{l}\text { Sees the vision as core to marketing strategy in } \\
\text { revitalising the brand }\end{array}$ \\
\hline MT3 & $\begin{array}{l}\text { Management team Premises } \\
\text { and estates lead for } \\
\text { company }\end{array}$ & $\begin{array}{l}\text { Sees the vision as core to renewing and growing } \\
\text { premises as part of revitalising the brand }\end{array}$ \\
\hline DT1 & $\begin{array}{l}\text { Manager - design team } \\
\text { DT2 }\end{array}$ & $\begin{array}{l}\text { Sees the redesign as a chance to prove the } \\
\text { excellence of the designs and the design team in } \\
\text { fulfilling them - wants to be ahead of the } \\
\text { competition }\end{array}$ \\
\hline DT3 & Designer - design team & $\begin{array}{l}\text { Wants other designers to see his work as leading } \\
\text { edge }\end{array}$ \\
\hline DT4 & Designer - - design tea & $\begin{array}{l}\text { Loves the vision, wants to see it carried through in } \\
\text { innovative ways in every pub }\end{array}$ \\
\hline DT5 & Designer - design team & $\begin{array}{l}\text { Wants to be known for designs recognised as } \\
\text { leading edge }\end{array}$ \\
\hline DT6 & Designer - design team & $\begin{array}{l}\text { Wants to see the vision fulfilled undiluted by } \\
\text { commercial side }\end{array}$ \\
\hline DT7 & $\begin{array}{l}\text { Online specialist- - design } \\
\text { team }\end{array}$ & $\begin{array}{l}\text { Wants online side designs recognised as leading } \\
\text { edge yet workable }\end{array}$ \\
\hline DT8 & Visualiser - design team & $\begin{array}{l}\text { Wants to show how traditional can be modern and } \\
\text { exciting, loves taking an artefact and making it a } \\
\text { theme }\end{array}$ \\
\hline
\end{tabular}

\begin{tabular}{|c|c|c|}
\hline Environmental stimuli & $\begin{array}{l}\text { Environmental } \\
\text { Dimension }\end{array}$ & $\begin{array}{l}\text { Holistic } \\
\text { environment }\end{array}$ \\
\hline $\begin{array}{l}\text { Signs and signals, the key artefact or } \\
\text { association to theme the pub }\end{array}$ & \multirow{3}{*}{ Physical dimension } & \multirow{6}{*}{$\begin{array}{l}\text { Perceived service } \\
\text { scape }\end{array}$} \\
\hline $\begin{array}{l}\text { Space and function } \\
\text { Furnishings, colours, art and layout } \\
\text { Scents throughout the day, food and beverage } \\
\text { signals } \\
\text { Media, TV, wifi, games }\end{array}$ & & \\
\hline $\begin{array}{l}\text { Ambient conditions } \\
\text { Temperature, light, music }\end{array}$ & & \\
\hline $\begin{array}{l}\text { Regional signs and symbols, belonging } \\
\text { Food and Beverage types and brands, } \\
\text { aspirations }\end{array}$ & $\begin{array}{ll}\text { Social } & \text { symbolic } \\
\text { dimension } & \end{array}$ & \\
\hline $\begin{array}{l}\text { Fascination, alignment and compulsion (to } \\
\text { return) }\end{array}$ & Natural dimension & \\
\hline $\begin{array}{l}\text { Brewery managers, tenants, designers } \\
\text { Other designers, other tenants, customers, } \\
\text { wider communities }\end{array}$ & Social dimension & \\
\hline
\end{tabular}




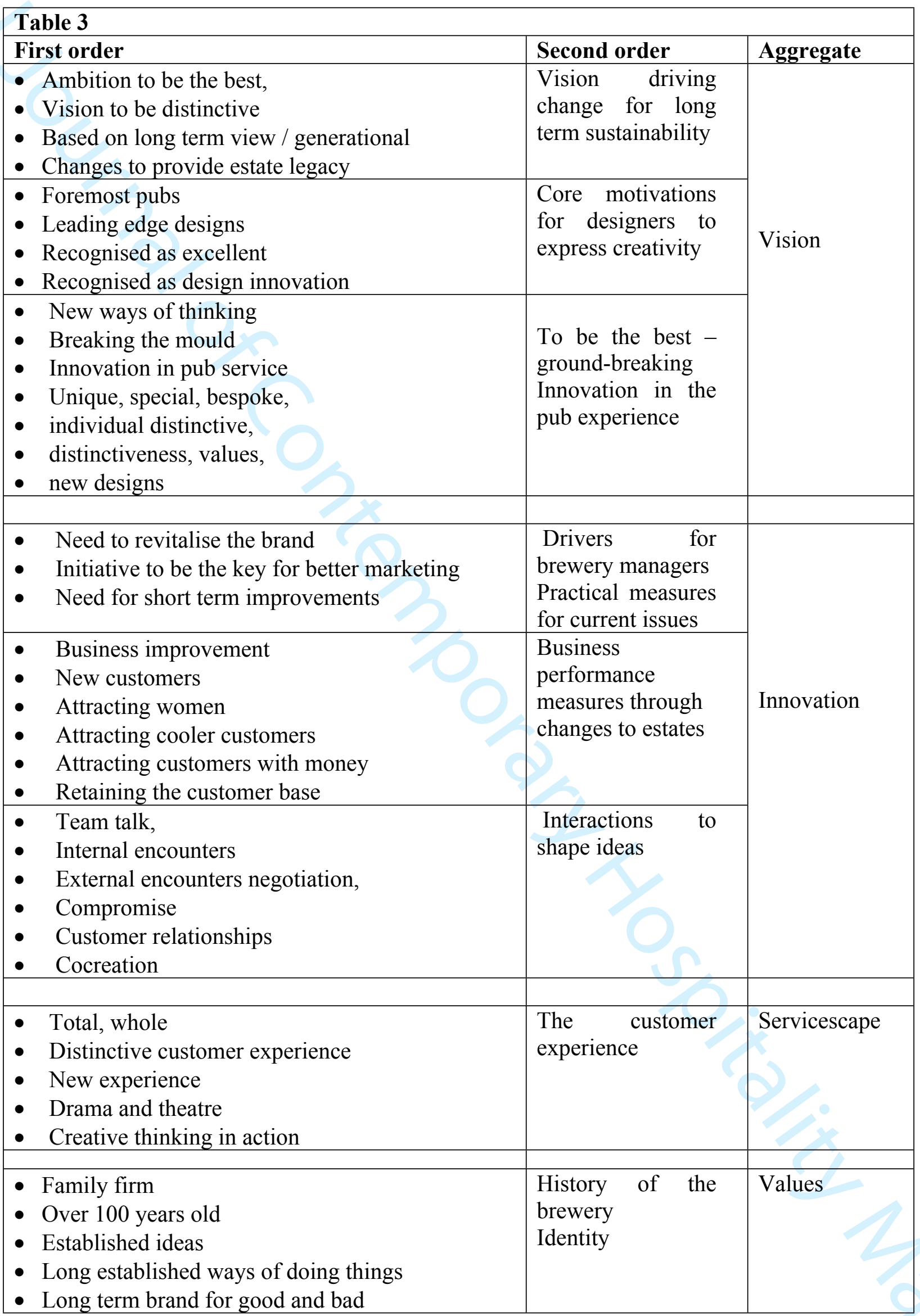


Figure 1. From Rosenbaum and Massiah, 2011, 473

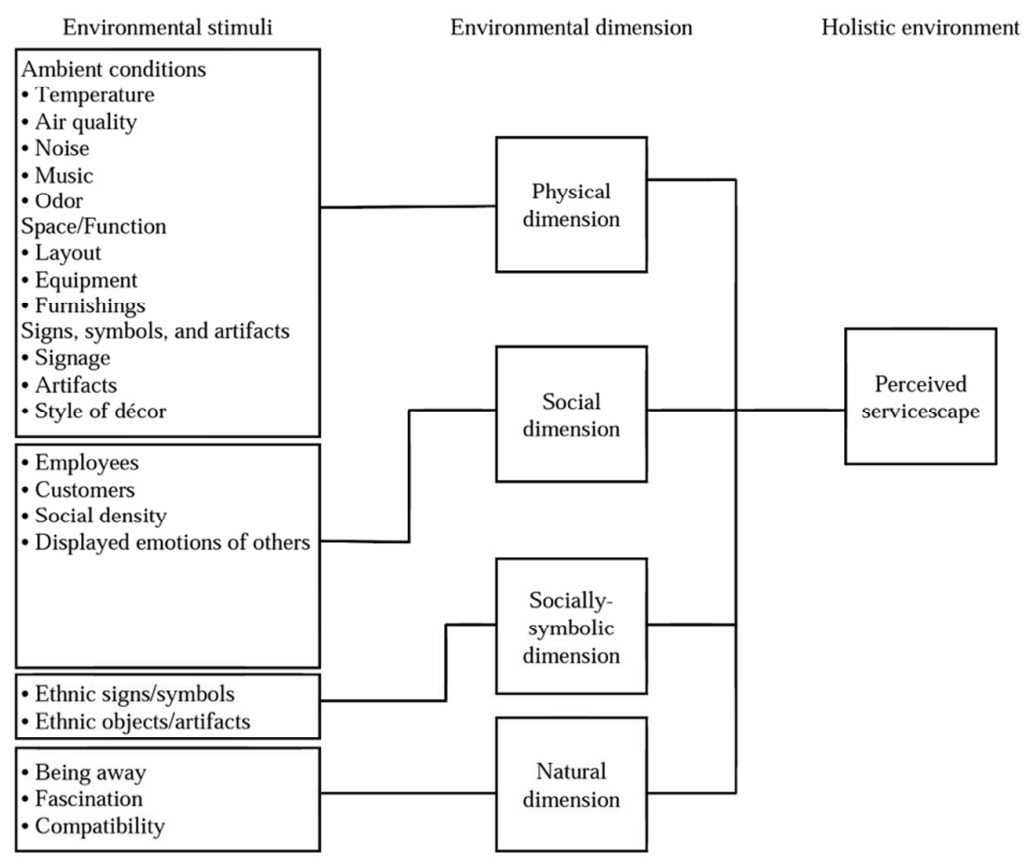

Figure 1. A framework for understanding four environmental dimensions of the servicescape

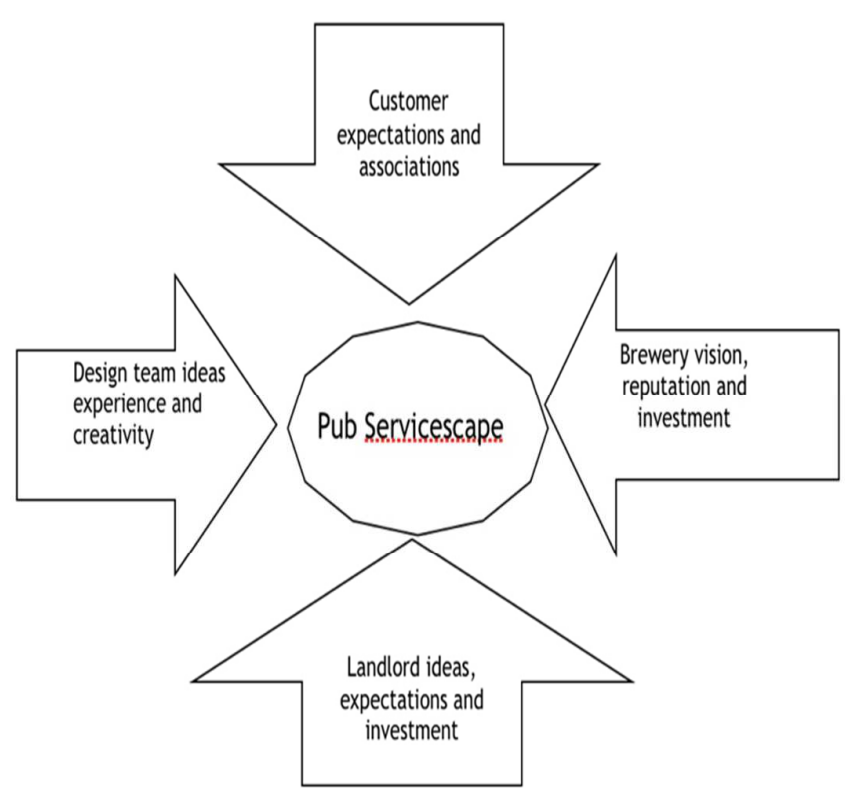

Figure 2. Pub servicescape. 


\section{Responses to the reviewers' comments and editorial instructions}

1. Replace the current abstract with a structured abstract. See author guidelines about how to write a structured abstract. Make sure to include all the subsections including implications and originality.

The abstract has been replaced in the required structure

2. Make sure to follow IJCHM author guidelines closely: http://emeraldgrouppublishing.com/products/journals/author_guidelines.htm?id=ijchm For example, when there are three or more authors, you need to use Adam et al., XXXX (or Adam et al., XXXX) format for the first time and after.

This has been checked

3. Revisit the Discussion and Conclusions sections one more time to better answer the "So What" question. There should be four sub-sections under this section: (1) Conclusions, (2) Theoretical Implications, (3) Practical Implications and (4) Limitations and Future Research. These have been rewritten and restructured as shown above

4. Cross check all references within text with your reference list. You may like to add more recent and relevant references published in recent months/years.

The references in the reference list all appear within the text.

5. Run your article through iThenticate, Crosscheck or any similar software to check the similarity between your study and previous studies. Try to minimize similarity percentage below $1 \%$ with any previous study. After you run your article's final version through iThenticate or other similar software, you should upload the similarity report to the system for our records.

The Turnitin similarity report has been uploaded. The report shows a 1\% similarity over a number of sources which are (a) cited and attributed references and (b) references in the reference list also cited elsewhere by other authors.

6. Keep your article below 9000 words including references, tables and figures. The body of the article has been reduced to ensure the total is less than 9000 including all references, tables and figures.

7. Proofread your article one more time and also you may ask a technical writer/copy editor to proofread it for you. After the manuscript is accepted, we will not ask you to proofread it again. In short, after I send you an official acceptance e-mail, you will not be able to make any further changes in your manuscript.

It has been proofread

8. Submit a clean version of your paper. You don't need to show/highlight all the changes made in the paper. I will read its final version anyway.

This is a clean version

9. Include a brief report showing how you have responded to the above requests. You don't need to show/highlight all the changes made in the paper. I will read its final version anyway.

This represents the report 
Reviewer: 1

Recommendation: Minor Revision

Comments:

What is the difference between your aggregate dimension of Vision resulting from Vision driving change \& Drivers for brewery managers or is there none? What is the difference between Innovation, Innovation/Vision and Innovation? This does not require a major rewrite of your paper but would bring your paper to a different level. To put it simply: Do all second order themes that lead to the aggregate 'Vision' lead to the same concept/idea of vision? Do all second order themes that lead to the aggregate 'Innovation' lead to the same concept/idea of Innovation? Etc., and if yes, why are they not put together to form a data structure tree? Furthermore, is there a conceptual connection (e.g., a perceived causal link) between 'Innovation' and 'Vision' through 'Drivers for designers to express creativity'?

The paper has been revised in its discussion of aggregates and the table has been revised accordingly

the rewriting of the conclusion section is minimal

This has been restructured in accordance with editorial comments to show additionally theoretical and practical implications, limitations and future research.

Reviewer 2

Recommendation: Minor Revision

Comments:

Results and discussion still do not go far enough to deal convincingly with the application of the concept to the sector

Practical implications have been added as a section in the Conclusions

While attention has been paid to general levels of proof-reading and referencing, there are still some instances where this can be improved:

The text has been rechecked and the errors identified by the reviewer have been corrected

At the same time, I feel that over-reliance on use of the term 'tenant' to provide a catch-all description for tenancies and leases (it is suggested that the company offers both types of 'ownership' on P3, L23) is misleading due to the length of agreements usually seen and conditions attached to agreements relating to investment and repair. Is it possible to make the distinction clearer in relation to both types of ownership or does your data not allow for this? In a similar vein, introduction of the term 'franchise' (P 2, L 42) is not helpful - your terminology needs to be far more precise when considering not only the UK reader but those outside of the great British pub circle who may currently find aspects of what you are saying confusing We used the term tenant as that was the way the participants referred to themselves. We appreciate that this may not reflect lease lengths etc and have amended the ownership reference on $P 3$.

Reviewer 3

None identified 